Peer review: This article has been subject to a double blind peer review process

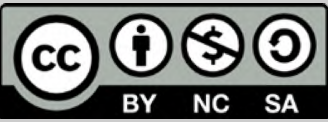

(c) Copyright: The Authors. This article is issued under the terms of the Creative Commons Attribution NonCommercial Share Alike License, which permits use and redistribution of the work provided that the original author and source are credited, the work is not used for commercial purposes and that any derivative works are made available under the same license terms.

\title{
Binary Framings, Islam and Struggle for Women's Empowerment in Bangladesh
}

Sohela Nazneen*

Address

*Correspondence: [s.nazneen@ids.ac.uk]

\begin{abstract}
In this paper, I investigate how binary framings of women's identity have influenced struggles for women's rights and the interpretations of the relationship between Islam and women's empowerment in Bangladesh. These binary framings position women at opposite ends by dividing them between 'Muslim/religious/moral/authentic/traditional' or 'Bengali/ secular/immoral/Westernised/modern'. I trace the particular genealogies of these binary constructs which emerged during specific historical junctures and are influenced by the shifts in regional and international politics. Drawing on primary research with women in religious political parties and women's movement actors and newspaper reports, I provide an account of how binary framings have been used by the Islamist actors and the counter framings used by the feminists to make claims over the state. I show how these framings have influenced the politics of representation of gender equality concerns, and reflect on what this means for possibilities of women's empowerment and strategies for resistance.
\end{abstract}

Keywords: Bangladesh, women's empowerment, gender, Islam, Hefazat 


\section{Introduction}

On 5 May 2013, Hefazat E Islam, a loose Islamist platform, composed of a dozen or so Islamist organisations, based at 25,000 madrasshas (Sabir, 2013) and allegedly financed by Saudi Arabia (Banyan, 2017) organised a sit-in in downtown Dhaka, Bangladesh's capital. It was attended by more than 500,000 people from all over the country (Boussou, 2013). A month ago it had organised a similar sit-in and had promised to return if the state failed to act. Hefazat was demanding the enactment of a blasphemy law and exemplary punishment for the on-line activists who criticised the Prophet Mohammed (PBUH) and insulted Islam in their writings. Its thirteen point demand to the government also included: the abolishment of the National Women's Development Policy ${ }^{1}$ and measures to prevent the 'infiltration of alien culture,' and 'a ban on immodesty, lewdness, misconduct and free mixing of men and women in public in the name of freedom of expression' (Sabur 2013).

These demands on limiting women's mobility, women's interactions in the public sphere, and control of women's dress and economic participation, are not unusual. The head of Hefazat, Moulana Shah Ahmed Shafi, described unveiled women as 'tamrind' (a popular sour fruit), implying that men have no control over themselves when they see an unveiled woman just as one has no control and starts to salivate at the site of tamrind (Dhaka Tribune, 2013). The show of strength by Hefazat, made actors working on women's rights question whether their positions and strategies were effective to protect the gains made so far and whether the state would backtrack and compromise on women's rights. 
Undeniably, the demands and framings used by Hefazat to mobilise support were anti-women. But they were based on an older narrative that placed Bangladeshi women in two camps - those who are 'religious/moral/good/traditional/authentic' and those who are 'secular/immoral/bad/modern/ Western'. These framings have a strong appeal and legitimacy among the wider public. The large numbers of Hefazat supporters brings home the fact that despite the rapid social development gains- attaining gender parity in girl's education, declining fertility rates and improved access to contraception, and improving financial and other services for women; a large number of Bangladeshis hold very complex and conflicted views on women's empowerment and rights (Jahan, 1995; Hossain, 2017).

In this article, I investigate how these binary framings of women's agency and identity influenced struggles over women's rights and the interpretation of the relationship between Islam and women's empowerment in Bangladesh. By examining particular episodes when these framings were deployed by religious political parties and religious scholars (ulema) and the counter framings developed by feminists, I trace the genealogies of these binary constructs and how these were influenced by the shifts in regional and international politics.

The examination of the genealogies of the binary framings and how they have influenced the struggle over women's empowerment in Bangladesh is important for several reasons. First, empirical research on Bangladesh questioning the binary framings and its implication on struggles for women's empowerment and over state accountability in light of the rise of Hefazat E Islam, are few. The existing scholarship on Islam, women's empowerment and Bangladesh has veered between development 
research that identifies Islam as a barrier to modernity and women's empowerment (Kabeer, 1989; Rozario, 1992) or research on political Islam, identity politics and their impact on women's rights and NGO work (Hashemi,2000; Shehabuddin, 2008a). The findings presented here contribute to the scholarship on Bangladesh by extending the analysis of women's religious subjectivities (Huq, 2008; Huq 2010) beyond the individual domain to the realm of politics. A focus on gender and Islam in a non-Middle Eastern, democratic, Muslim majority country also contributes to the body of scholarship on Islam and gender studies, which generally privileges the Middle Eastern and North African countries, Iran, Turkey and to some extent Pakistan (Shehabuddin, 2008b).

Second, this article demonstrates the importance of taking the broader context into account when interpreting the mutually constitutive relationship between religion and women's empowerment. Scholars have long highlighted that women belonging to the Islamist movements are able to exert considerable agency. They also point out that women's engagement in Islamist movements can be read as a resistance against Western imperialism or as a failure of modernising projects of oppressive regimes (Mahmood, 2005). Bangladeshi scholars have used this understanding of women's religious subjectivity to explore women's agency, the multiplicity of women's subjective positions and selfactualisation through construction of the virtuous-self based on the good/moral/authentic/Muslim womanhood (Huq, 2008; White, 2010; Naher, 2010; Hussain, 2010; Huq, 2010). However the construction of this virtuous-self based on the good/moral/authentic/Muslim womanhood by the women in the organised religious groups have implications for the room available for 'bad/immoral/ Westernised' Muslim women or secular or non-Muslim women in Bangladesh in negotiating rights and empowerment with society at large and the state. The construction of 
group identities through Qu'ran reading classes and engagement with religious political parties, have implications beyond individual change. How is this group identity deployed by the women and also used by other actors to attain political goals?

In the next section I discuss my positionality and methods used to collect data. I provide a brief overview of how religion and politics are intertwined in Bangladesh and the major developments in Bangladesh politics in the next section. I also discuss the specific historical junctures when these binary framings emerged. A brief analysis of the main trends in scholarship on women's empowerment and religion in Bangladesh in the third section reveals how the relationship between women and Islam is interpreted and unpacked by scholars producing knowledge on women's empowerment. Some of this analysis uses these binary framings. Based on my interviews and secondary data, I provide an analysis of some of the key episodes during the last and present decades where these binary framings were used by the Islamists against the women's rights activists to delegitimise their claims. I also explore the counter framings used by the feminists to advocate for women's rights. In the last section I discuss the implications of these binary framings for women's empowerment and state accountability.

\section{Positionality and methodology}

The primary research used in this paper was conducted for a large research programme consortium -the Pathways of Women's Empowerment funded by UK Aid through the Department of International Development. The data is drawn from three research projects conducted between 2008-2011. The data collected from these projects were supplemented by newspaper 
scans and web materials collected during 2013-14 when Hefazat had placed its thirteen point demand. This supplementary data allows me to comment on how binary framings were being deployed by Islamist groups and the women's movement during episodes of contention at different points of time. It is not possible ascertain whether the response collected on how different actors viewed these contentious episodes would have been the same if data were collected in 2018. However, the secondary sources consulted for this article shows that the positions of these different groups have largely remained unchanged or hardened over time.

The three research projects mentioned above include: one on women's movement actors and their constituency building strategies; another on women in religious political parties; and the last one on the conceptualisation of women's empowerment by different actors in Bangladesh. The research with women's rights activists focused on three national level organisations mobilising around specific gender equity issues. The members of these groups interviewed were professional middle-class women. The methods included semi structured interviews with twenty key informants, secondary document analysis and validation workshops with all three organisations. ${ }^{2}$ The research on women in religious political groups focused on how urban-based middle to lower middle class women perceived specific policy changes. The methods included: newspaper scans of five dailies with different political leanings on selected policy debates, statements made by religious political parties on these policies, analysis of party manifestoes and publications on women's rights, twenty life histories with selected women leaders, ten interviews with male leaders, and four group discussions with women's associations linked to these parties and Qu'ran reading groups. The research on the conceptualisation of women's empowerment used secondary document analysis and archival research. 
My own and the research team's positionality influenced the access to the three women's rights organisations and also the religious political parties and Qu'ran reading groups for women. Gaining access to women's rights groups as a feminist academic was relatively easier as the members of these groups were familiar with my work and that of fellow colleagues. Access to the religious political parties and Qu'ran reading groups proved to be a challenge. We used the informal networks our team members had built through their previous work to approach the interviewees. Preexisting informal relations allayed the resistance that we may have faced as researchers working on women's rights. While the existing informal connections were useful for initial contact, we, then, had to formally approach the female interviewees through the male leaders we interviewed. This was a necessary step as the female members of the religious political parties wanted to ensure that they had permission from the party hierarchy.

My position as a feminist academic, who was based in and has deep connections to Bangladesh, influenced my interpretations. I hold specific views on the policy cases discussed here. I had to challenge myself to reflect on how my own views might limit my understanding of the positions taken by the women belonging to the religious political parties and Qu'ran reading groups. I am a political economist by training. I largely focus on the role played by religious political forces in formal politics. The political economy analysis was useful for moving beyond the focus on women's subjectivities and for unpacking how ruling elites maintain power through balancing various group interests, including interests promoted by women's rights actors. It also helped to explore how shifts in the powerorganisational, ideational and material, held by different groups (including 
women's movement actors and the Islamist groups) influences the actions taken by the political elite.

\section{Islam and Politics in Bangladesh: Genealogies of Binary Framings}

Tracing the genealogies of these binary framings that divide Bangladeshi women in two camps requires an exploration of the unresolved question around Bengali Muslim identity. Bangladeshis are ethno-linguistically Bengali. About 1.3 per cent of the population are non-Bengali and about 12 percent are non-Muslim (BBS, 2010). Bangladesh gained independence from Pakistan in 1971. The two units of Pakistan were created by dividing the subcontinent into India and Pakistan; the latter was created out of the Muslim-majority provinces. Pakistan proved to be a short lived project as the division of resources between the two units became increasingly lopsided (Sobhan, 2015; Jahan, 1972). The attempts to 'purify' the Bengali language (i.e. Bengali written in Urdu script, a ban on works of the Nobel Laureate poet Tagore) and culture (ban on Tagore songs or critiquing saris as immodest covering) into a more Islamic form by the West Pakistani government antagonised the Bengalis against the use of Islam to justify dominance (Azim, 2017).

Bengali cultural/linguistic identity and secularism gained prominence in the mobilisation against West Pakistan's rule. The refusal to hand over power by the West Pakistani political elite after the Bengalis won a resounding majority in the national parliamentary elections in 1970 and the army crackdown in 1971 meant inevitable separation of the two units. Given that a common religious identity had failed to deliver on development and national unity, and that the Bengalis had mobilised around a cultural-linguistic identity and secularism, meant that after 
independence Bangladeshis had a difficult time reconciling both identities in the political sphere. These identities were pitted against each other by the political parties over the years to gain political legitimacy and support (Yasmin, 2016).

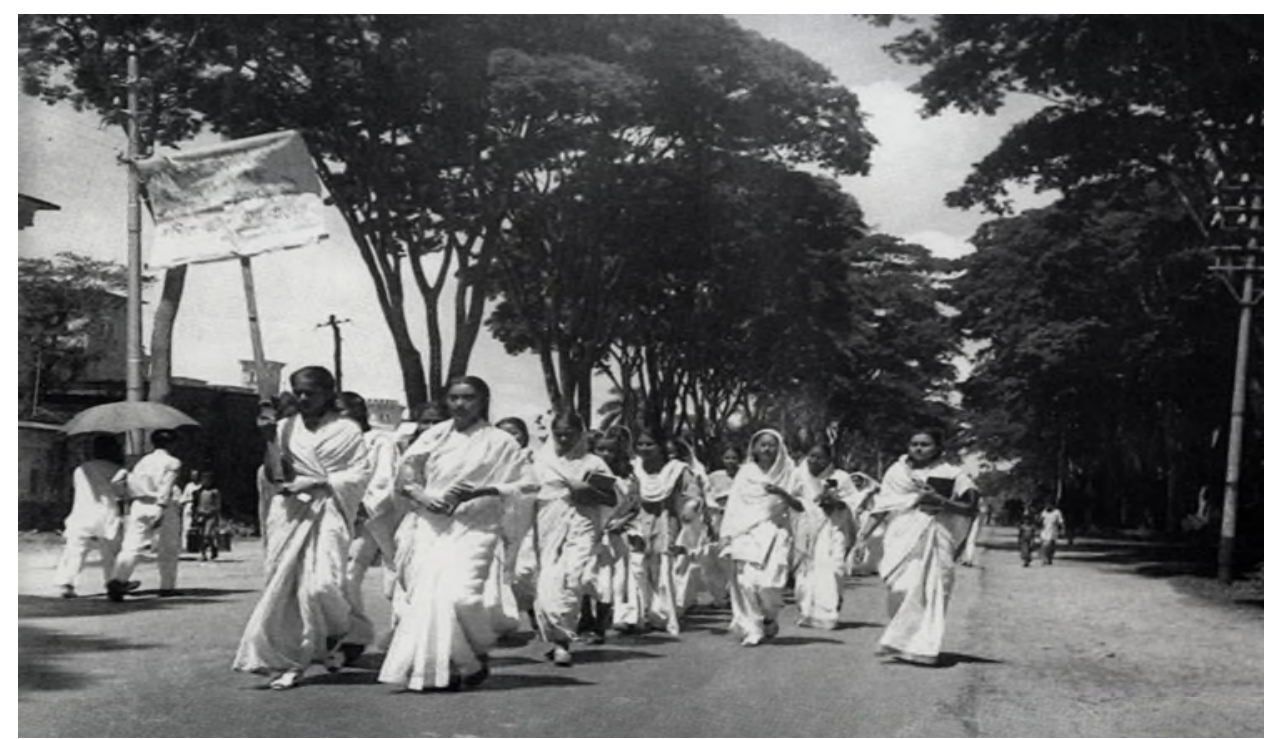

(Women protesting during language movement, University of Dhaka, February 1953. Available at:

https://en.wikipedia.org/wiki/1971 Bangladesh genocide\#/media/File:21 Feb 1953 D haka University female students procession.png)

Gender has a central role in interpreting the relations that exists between the state and society in Bangladesh. The 'woman question' divided the Bengal Muslims into two camps. The traditionalists drew on the revivalist traditions from the Middle East and wanted to preserve orthodox notions of Islam. The modernists advocated reform which included education for women, relaxation of extreme purdah norms and women's participation in public life à la Turkey (Jahan, 1995). These positionings constructed a dichotomy between Islam and the modern during the colonial era. The dichotomy came to the forefront during the nationalist struggle for independence. Women became the markers and bearers of Bengali culture. Visions of modern and secular Bangladesh included specific visions 
about women's position and status that was distinctively different from the traditional notions espoused by the religious quarters (Azim, 2017).

Bangladeshi politics is dominated by two major centrist political parties. The Awami League, a centre-left party, led the nationalist struggle. The Bangladesh Nationalist Party (BNP), a centre-right party, was founded by General Ziaur Rahman, after he took over power in the mid-1970s. Both of these parties led the struggle for democracy in the 1980s against General Ershad (1982-1990). The political Left has a very weak presence in Bangladeshi politics (Hassan, 2013). The religious political parties have steadily gained ground in the public sphere since the creation of the state. Electorally the largest Islamist party, Jamat I Islami, has secured between four to eight percent of votes in national elections since 1991, and has been in the coalition government through tacit or overt alliances with the AL or the BNP since 1991 (Siddiqui, 2006; Hassan and Nazneen, 2017). This significantly raised the Islamic bloc's power (Siddiqui, 2006;).

The Constitution formulated in 1972 included secularism as a key principle but this was removed by Ziaur Rahman and replaced with 'faith in the almighty Allah'. In 1977, Ziaur Rahman also allowed for religious political parties to function. These changes were made to consolidate Bangladesh's identity as a Muslim majority country and to strengthen ties with the Middle East. The religious political parties were banned by the AL given Jamaat and other groups had supported the Pakistani army during the liberation war in 1971 (Riaz, 2014). General Ershad further blurred the boundaries between the state and religion, when he pushed for the Eighth Amendment to the Constitution, which declared Islam as the state religion in 1988 (White, 2010). Secularism was included as a principle again in the Constitution after a Supreme Court verdict led to another amendment of 
the Constitution. However the Eighth Amendment was not removed from the Constitution ${ }^{3}$ (Yasmin, 2016).These shifts indicate the increasing dilution of secularism and the rise of religion in politics.

While secular nationalism was useful in defeating the two nation theory and in separating from Pakistan, once this aim was achieved, the appeal of secularism waned among the wider public, especially the middle class. Religious nationalism had served the Bengali-Muslim elite and the nascent middle class well in countering the dominance of the Bengali-Hindu elite and to push for the division of India in 1947. In fact, religious nationalism has steadily gained space since the 1990s, which has led to increased questioning of placing Bengali identity along with the secular, and a reexamination of how religion can be accommodated with the cultural identity in public discourse.

The rise of religious nationalism and the dilution of the secular have meant that the state and the political parties hold contradictory positions when it comes to religion. This contradictory position is not entirely new. Women's rights have featured prominently in these negotiations between the ruling regimes and their religious political allies. The religious parties and the ulema have significant veto power in areas that pertain to the cultural, which includes women's position in the family and in the public sphere (Nazneen and Masud, 2017). This veto power comes from the legitimacy these actors have over determining the boundaries of what is religiously permissible. The mainstream political parties have to balance between their position as 'modernisers' which means engaging women in the economy and visibilising women, while also ensuring that their electoral legitimacy is not eroded by being portrayed as anti-Islamic. This need to balance has deepened as more and more Bangladeshis migrated to the 
Middle East (primarily to Saudi Arabia) and were exposed to the cultural practices and brought these conservative practices based on Wahabi Islam back to Bangladesh (Kabeer, 1991; Harrison, 2015).

Aid dependency during the decades of the 1970s, 1980s and 1990s meant that the Bangladeshi state pursued a women's development agenda to secure funds and gain international legitimacy. In the last two decades aid dependency has significantly reduced (only 2 percent of the annual budget), but the development and NGO sector work remains donor driven (Hossain, 2017). Foreign funding has shaped the gender and development agenda in Bangladesh as issues that gained prominence in international development were prioritised to secure funding. The decades also witnessed the growth of a large foreign-funded NGOs sector that targeted rural poor women in their programmes on microcredit, health, education, and legal aid (Hossain, 2017). The growth of the NGO sector created scope for women's rights actors to engage in designing development programmes and create allies for promoting women's rights (Nazneen and Sultan, 2014). But this engagement came at a price as the availability of international funding influenced the women's rights agenda and the autonomous nature of the movement was questioned by the wider public (Chowdhury, 2009). Women's movement actors have struggled to retain their legitimacy as representatives of women's interests. They have packaged their demands in a manner so that they would not be branded as 'inauthentic/Western/elite' (Nazneen and Sultan, 2014).

At present, Bangladesh is at a critical juncture where changes to the social and cultural fabric is taking place at a fast pace. Recent years have seen a rise in the number of organisations funded by Middle Eastern countries providing services to the rural and urban poor. Significant funds have been 
invested to establish hospitals and Islamic schools (both madrassh and English medium schools). ${ }^{4}$ There is also an increase in veiling and public practice of Islamic rituals (namaz) among the wider public (White, 2010). This shift in the public presence of Islam is accompanied by the growth of the new middle class and a moneyed elite class whose position on religion's presence in public life is different from the old cultural elite, who played an active part is emphasising Bengali nationalism and viewed religion as belonging to the private domain (Yasmin, 2016). Several factors have influenced the middle class to push for a more overt presence of religion in public life. These include: the rise of religious nationalism since the 1990s; the need to reassert a Muslim identity given global and regional push-back against Islam in the last decades; and the change in access to communications technology and the rise of popular TV and other types of virtual platforms that promote a more austere and pure form of Islam.

After 9/11 Bangladesh also witnessed the presence of home-grown extremist groups such as the banned Jamat-UI-Mujaheedin (JMB) that carried out a series of bombings in 2005 (Griffiths and Hasan, 2015). Bangladesh also witnessed an increased presence of globally connected networks such as Hurkatul Jihad-I-IsImai Bangladesh (HUJI-B), and other groups such as Jagrata Muslim Janata Bangladesh (JMJB), Ahle Hadith Andolon ( $A H A B)$. These groups reject the secular/liberal laws and systems of governance and demand an establishment of Shari'a law and systems in Bangladesh. They have carried out attacks against state officials, scholars and on-line activists (Griffiths and Hasan, 2015). While links these extremist groups may have with the local Islamist political parties or with Islamist civil society organisations is debatable, their sporadic activities have created a sense of vulnerability among the liberal scholars, activists and civil society organisations. The latest in the strings of attack was carried out by an extremist group which claimed a link to Islamic State (IS). 
The attack on the Holey Bakery in 2016, a popular cafe in Dhaka, drew international attention given all foreign hostages were killed by the extremists (BBC, 2016).

The state is currently cracking down on these networks. Needless to say, the rise of anti-Muslim views in the West and in neighbouring India has created a sense of marginalisation and powerlessness among the Muslim population. The state is under pressure to demonstrate that it has a clear position regarding Islam in public life. The waning power of the Western donors as Bangladesh becomes less aid dependent means that donors have limited influence over the political elite. These shifts in regional and international politics have created a complex situation.

\section{Gender Binaries and Scholarship on Women's Empowerment and Religion}

'Does religion empower women?', is a vexing question that the scholars researching women's empowerment in Bangladesh have had to grapple with. There are four overlapping bodies of scholarship on religion and women's empowerment (White, 2010). These bodies of work illustrate the way binary framings have influenced interpretations on women's empowerment in Bangladesh and the attempts to move away from these easy binaries by the feminist scholars.

The development literature on women's empowerment from the 1970s to the mid-1990s discuss religion mainly in relation to purdah (Women for Women, 1975), women's rights contained in religious texts and its influence on existing law (Sobhan, 1980), and ethnographic studies that 
explore local religious norms (Hartmann and Boyce, 1983; Rozario, 1992). The focus of these studies is on the modernisation of women through economic, social and political participation (White, 2010). These studies position religion as traditional/backward that constrains women against the modern.

The second strand includes political studies conducted during this period that focus on Islamisation of the state and its negative impact on women's empowerment (Kabeer, 1991; Jahan, 1995). These studies point out that the state has a contradictory position when it comes to women and Islam. Reliance on aid meant that the state had taken an instrumental position and promoted women's inclusion in the economy and the public sphere. However the need for political legitimacy led the political parties to take measures to bring back organised Islam into politics, allowing Islamist groups to function within public universities and Islamist newspapers and media to flourish (Karim, 2004).

The third strand of scholarship which began largely in the mid-1990s explored the politics of religion in the society. These studies focussed particularly on the attacks on NGOs by the Islamist groups and fatwas in rural areas against women (Hashemi, 2000; Naher, 2010). Studies also analysed discourses around the fatwa on Taslima Nasrin, a writer, for promoting minority and women's rights and critiquing Islam (Hashemi, 1995). These studies explored how the 'politics of representation surrounding gender, modernity and Islam' (White 2010, p. 338) is repeatedly acted out in the personal, family and community life and in programmes and policies pursued by NGOs, development agencies and the state at local, national, global levels. Religion in these analyses by Bangladeshi and international scholars is seen as an antithesis to women's 
empowerment and religious groups are associated with 'traditional/backward/moral/authentic' vis a vis women in development programmes who are identified with the secular/modern/progressive.

Recent feminist studies have questioned these easy binaries and explored how 'women are caught between...contradictory movements at the local/global levels' (White 2010, p. 338), and how women negotiate or exercise agency by subverting, resisting or using religious framings (Shehabuddin, 2008b; Huq, 2008; Huq, 2010). The emphasis on the latter two studies is to show that women's agency within religious structures and participation in religious groups do not necessarily translate into extremist activities. This interpretation is influenced by the analysis forwarded by Mahmood (2005). These studies are also a reaction to correct the simplistic interpretations that exist in the scholarship on Islam in the West that equates religiosity with extremism. The work produced by the Bangladeshi scholars should not be categorised under another strand of work prevalent in the West that valorises all forms of Islam and equates any criticism of the religion as Islamophobic. However work produced by Bangladeshi scholars does not undertake an analysis of the political implications of the creation of these apolitical organised groups. Furthermore the broader questions on what the creation of these seemingly apolitical but organised group identities based on religion mean for other women who do not belong to these groups and women's empowerment, remain largely unexplored.

\section{Contentious Episodes and Strengthening of Binary Framings}

In this section, I examine selected episodes of contentions between the Islamist groups and women's movement actors to reveal how binary 
framings have influenced debates over women's agency, identity and empowerment in the recent decades. I focus on the movement against Islam being declared as the state religion, the anti-fatwa movement and the mobilisation around the National Women's Development Policy, 1997 (amended 2004; 2011) as cases to illustrate how binary framings influence struggles over women's empowerment.

In the debates over women's rights and empowerment in the 1980s and 1990s, women were 'set up as key bearers of symbolic opposition between the mullahs who were retrogressive and women as advocates of modernity' (White 2010, p. 338) by those working in development. While this interpretation placed women and religious political parties and the local religious authorities in contention with each other, an analysis of the positions held by the latter groups show that this interpretation does hold merit. While modernity need not be conceptualised as liberal and Western,' the predominant understanding of modernity at that time in Bangladesh was influenced by this notion. The opposition to women's empowerment and rights agenda came from rural patriarchy aided by local mollahs who wielded limited power. Women's rights activists were willing to engage with this group to gain support for development interventions, even though the feminists were aware that they were stereotyped by the rural mullahs as 'immoral/Westernised/secular/inauthentic'.

One of the women's rights activists I interviewed said:

[W]e had to engage to get them on board... to ensure marriages were registered and women could come to the meetings... To them we were short haired, Westernised/elite women, but we came from urban areas 
and from a different class and we talked about the state law (they feared the state then) - which helped. (Feminist lawyer 1, March 2009)

However, 1988 proved to be a turning point for women's rights activists as they decided to publicly protest and file a case against the Eighth Amendment to the Constitution which declared Islam as the state religion (Azim, 2017). General Ershad pushed this through to secure political legitimacy. Various civil society groups protested the blurring of boundaries between religion and the state and the risk it posed for the religious minorities. The women's movement actors were unequivocal that this change violated the spirit of the Liberation War (ekatur-erchetona / arodsho) and that religion should remain in the private sphere. The iconic slogan jar jardhormo tar tarkache, raste-r tatekibolar ache (religion is a private matter what does the state have to do with it) was used to mobilise in the streets of Dhaka. Women's organisations led these public protests.

This specific interpretation of secularism in the European sense went beyond the established interpretation that secularism means dhormoniropekhota or 'equal rights to all religion and freedom of religion'. It is this interpretation that is currently espoused by the general public in Bangladesh. Women's movement's stance in this matter has created a distance between them and the general public. Women's rights groups' position on the Eighth Amendment is criticised by the Islamist groups and political parties using binary framings. These critiques framed women's rights activists as Westernised urban elites who are 'immodest/immoral' (interview, Islami Okiyo, Jot leader 1, February 2011), and who do not represent the views of Bangladeshi women on the role of Islam in public life. The religious leaders, during the 1980s, argued that women's rights activists were 'possessors of dangerous visions that would turn Bangladesh 
into Turkey' (i.e. a secular republic), and that this vision undermined Bangladesh's identity as a Muslim majority country.

Expansion of development activities during the 1980s and 1990s by the women's rights organisations and NGOs specifically targeting rural women also rattled the religious groups. ${ }^{5}$ The religious groups attempted to undermine the development work undertaken by the NGOs and women's organisations by questioning whether these groups were the 'real representatives' of rural women's interests and concerns. The religious quarter presented a narrow role for women in the society -that of the mother and the dependent wife and discouraged women's engagement in the productive economy. The religious leaders attempted to delegitimise development work by branding women's rights activists and NGOs as 'agents of capitalism/imperialism'. They pointed out that NGOs engage rural women in exploitative relations of production through credit programmes. They stressed that women's movement's support for expansions of these development programmes disempower rural women (interview, Khelafat Majlis leader 2, March 2011).

The 1990s saw a transition to democracy after the fall of General Ershad. Women's movement actors' significant role in the anti-authoritarian movement along with international events such as the Beijing Conference opened up policy spaces for the women's movement actors. Throughout the 1990s, Islamist groups and women's rights groups came to loggerheads several times over different issues. One of them was the Taslima Nasrin affair. A fatwa was issued against Nasrin for critiquing the Qu'ran in her book. The women's movement groups came out in support of Nasrin arguing for freedom of expression and denouncing the misuse of fatwa. But they were sharply divided among themselves as many felt Nasrin's 
comments were insensitive and had damaged the gains made by the movement (Hashemi, 1995). The Islamist political parties and the ulema grabbed this opportunity to portray women's rights groups as Westernised elites whose position on personal freedom and secularism undermined Islam (Hashemi, 2000). ${ }^{6}$

It was during this period that the use of fatwa against rural women for violating sexual/social/religious norms (i.e. pre-marital sex, extra-marital relations, violation of purdah norms) by local imams and mollahs gained attention. Women's movement actors intervened in specific cases, filed complaints, and mediated at the local level on behalf of the victimised women. Women's groups at the national level, particularly feminist lawyer groups, were able to intervene because of their members' class positions and networks. They also demanded legal change and argued that it was a modern state's obligation to protect its female citizens (interview, feminist lawyer 1, March 2009).

In 2001 the High Court issued a suomoto rule that fatwa could not be issued by mullahs. This ban became a rallying point for the ulema and religious political parties ${ }^{7}$ to mobilise against state's encroachment on the rights of the ulema. It was interpreted as an effort to secularise and undermine Islam (Interview, IOJ leader 1, March 2011). Interviews with male political leaders of Khelafat Majlis and Jamaat I Islami revealed that the former opposed the ruling on the ground that Bangladesh was not a secular 'Western' state and the latter felt there was no democratic dialogue and that a blanket ban did not meet the needs for religious guidance by the people (interviews, Khelafat Majlis leader 1, March 2011; Jamat I Islami leader 2, January 2011). They argued that women's rights and entitlements were clearly defined in the Qu'ran, and implementation 
of the provisions made in the Shari'a would ensure justice for women. They also argued that the Western notion of equal rights failed to protect women from violence and complementarity of gender roles ensured better protection of women.

The women's association with close links to Jamat I Islami held similar views (group discussion, Nari Odhikar Andolan ${ }^{8}$, March 2011). While these women largely endorsed the views of the parent political party when it came to the need for democratic dialogue and the complementarity of gender roles ensuring women's rights, there were some divergences. When questioned about the use of fatwa against rural women and the work done by women's rights activists they were ambivalent. They were unable to deny the misuse of fatwa but argued that the members of women's rights groups were 'not schooled in figh and had limited engagement at the grassroots level'. The group pointed out that women's rights activists had limited understanding of the value of fatwas in the lives of people in need of guidance (group discussion, Nari Odhikar Andolon, March 2011).

The ban on fatwa was later taken up by Hefazat E Islam to rally support. Appeals were filed in the Supreme Court by two religious scholars, which led to the partial revoking of the ban. Undeniably, the actions by Jamaat I Islami and ulema and the position espoused by the women's groups associated with Jamaat, meant curtailing freedom of expression, and in the case of the partial revoking of the ban on fatwa, adversely affecting the rule of law and women's status. 
The discussion above demonstrates how binary framings were used by the religious political parties and the ulema to delegitimise women's rights work and the women's rights advocates. It also shows how women rights actors attempted to counter these by using the language of rights, state obligation, and by alluding to the spirit of the Liberation War. But the limits of these counter-framings and the appeal of the binary framings become clear when we turn our attention to the National Women's Development Policy (NWDP).

The NWDP was formulated in 1997 by the state to meet its international obligation imposed on UN member states by the Beijing Platform for Action (PFA). The Bangladeshi state also wanted to enhance its gender friendly reputation. The 1997 policy contained visions and actions points for all critical areas identified under the PFA (Shahid, 2017). The policy was later used by the women's movement actors to exhort the government to take action in specific areas by reminding the state to meet its national and international commitment (interview, women's rights activist 3, June 2008).

However, it was alleged by the Islamist groups that NWDP contained a clause that demanded equal property rights for women (interview, Jamat I Islami leader 2, March 2011; Islami Oikyo Jot leader 1, March 2011). In reality the policy contained no such clause. In 2008, protests were organised by Islami Okiyo Jot (IOJ), arguing that the policy was against Qu'ran and Shari'a (Shahid, 2017). The women's rights groups also formed an alliance composed of 40 women's groups which protested the government's decision to form a review committee that included Islamic clerics. They argued that the ulema were against the spirit of the Liberation War and trying to promote fundamentalist politics (The Daily Star, 2008). 
In interviews with male Jamat I Islami and IOJ leaders it became clear that apart from the issue of equal inheritance, the bone of contention was that the policy states that the state will fully implement the CEDAW. Article 2 of the CEDAW requires the state to reform all gender discriminatory laws which would mean changes in religious personal laws that govern marriage, divorce, inheritance, and custody (interview IOJ leader 2, March 2010).

The women's association closely linked to Jamaat did not diverge radically from the position held by the parent political party. They felt that the policy did not fall within the Islamic framework and needed to be revised. When probed about the question of inheritance, particularly property being important for poor women in rural areas, they argued that complementarity of gender roles meant that women can depend on male members of the family. They also argued that men should inherit the larger share as they are providers (group discussion, Nari Odhikar Andolon, March 2011). Interestingly, none of the members had read the policy.

Their views on the position taken by the women's rights groups was similar to that held by the male party leaders, that the women's movement was misdirected as these actors demanded equal rights based on the Western conceptualisation of rights. They argued that women's movement actors failed to understand that men inherited a larger portion as they had responsibilities from which women were exempted. They pointed out that the Islamic position of daughters inheriting half of what the sons receive was fair given that the majority of women in the Bangladesh did not bear responsibilities of their parents and extended families. This position held 
by the male political leaders of Jamaat and the women's group associated with the party, of course, did not take into account that female headed households may be bereft of male guardianship or that in many cases male members are unwilling to meet their duties as providers.

The debates over the policy created a stir within the female Qu'ran reading groups, which are apolitical but many members have connections with Jamaat E Islami and other Islamist political parties. Interviews with women from one such group (all were professional women) revealed that they viewed family law reform as unnecessary which was similar to the views held by these parties. They also argued that the international conventions (CEDAW) were framed by Western countries, and these conventions are designed to undermine Islam and promote Western values. They felt that the UN and other organisations were not legitimate as these organisations were biased towards powerful Western countries. These arguments were also put forward by the male political leaders of Jamaat I Islami and other political parties.

When probed about whether women in the Qu'ran reading groups would be active in opposing the policy, they pointed out that they had discussed the policy at the community level meetings and have made public statements wherever possible. Whether they would come out onto the streets would depend on the leaders of the religious political parties. The women also argued that the women's rights groups should not claim they represent Bangladeshi women's interests, as these groups were not 'rooted in the real culture and beliefs of the country' (group discussion, Qu'ran reading group 3, March 2011). 
Even though the caretaker government had withdrawn the draft NWDP in 2008 , it became a rallying point for garnering support for a range of Islamist actors and religious political parties. In 2011, a new draft policy was introduced by the AL which called for equal access for women to credit, land, and labour markets but it did not make any mention of legal changes to ensure equality of marriage, inheritance, divorce or custody in line with the CEDAW (Shahid, 2017).A series of national protests were led by the IOJ against the policy. The religious political parties also changed tack. They formed Hefazat E Islam, an Islamist civil society alliance, to counter the alliance created by the women's rights activists. Hefazat was not explicitly linked to any political party but drew widespread support of the ulema and the general public (The New York Times, 4 April 2011).

The ulema portrayed the protest against the policy as a responsibility of all Muslims. They argued that the democratic principles required a dialogue on any policy and that they had the support of the majority (interview, IOJ leader 1, March 2011). Emphasising that women's needs were met in a just and fair way under the Shari'a, they argued that the government was a puppet in the hands of secularists/Western elite (interview, KhelafatMajlis leader 1, 2011). The Westernised/elite/liberals, including the women's groups, were branded by the ulema as 'Kolkata Haji,' meaning who had performed the haj in India and took their instructions from 'Hindu' India-the 'other' in Hefazat's imagination. The reference to India was to undermine the demands made by the liberal/secular quarters.

The women's movement also organised protests to counter these allegations (Haq, 2011), again emphasising the spirit of 1971 and obligations of a modern state towards its female citizens. In their framings, women's movement actors argued that unless Hefazat was contained, 
Bangladesh's situation would be similar to that of Pakistan. However it was palpably clear that in street politics, women's movement activists were at a disadvantage, given their smaller numbers. As Hefazat had overtly disassociated itself from Jamat I Islami, it meant that the exhortations by the women's movement about the spirit of 1971 as a counter mobilisation strategy worked less well. This is because Jamat was culpable of the war crimes in 1971 and not the ulema. Also there was a disjuncture between the women's movement and how the large majority of the rural population and the new middle class perceived the role of religion and women's empowerment. These groups believed in women's right to work, healthcare, and education but they did not want to challenge the religious personal laws that governed private lives and also the core patriarchal structures.

In the end the policy itself was passed by the Cabinet. However NWDP came to symbolise the rise of the religious right wing in the shape of Hefazat E Islam, a deepening of the rift between religious and secular in the society, and with women's movement actors losing clout (Nazneen and Masud, 2017). The AL which passed the policy later backtracked on its implementation. Ministers made public statements about taking into account the particular context in Bangladesh which was not amenable to all the provisions made in the CEDAW (Shahid, 2017).The abolishment of the policy was later included in Hefazat's thirteen point demand that was discussed at the beginning of this article. 


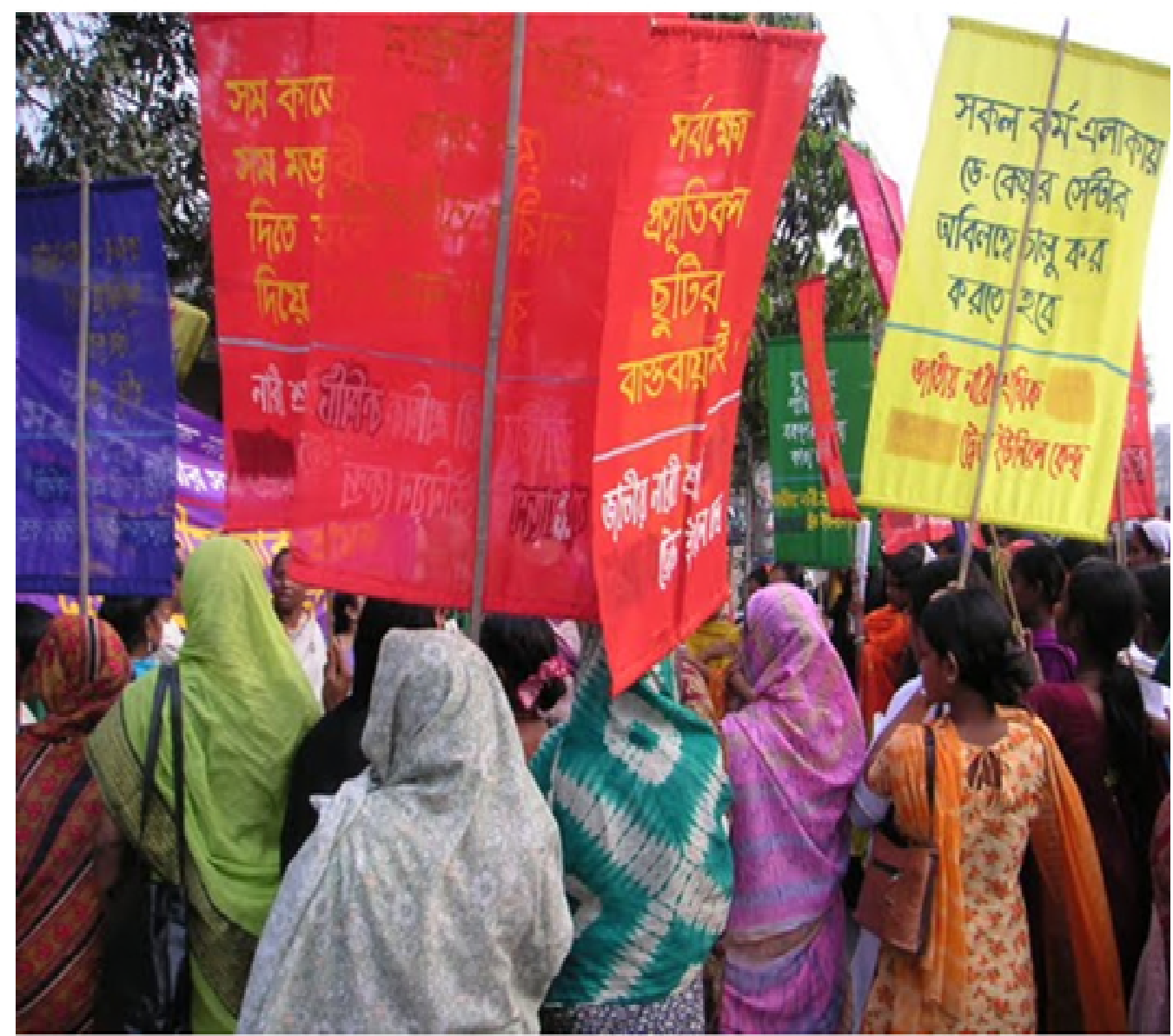

(8 March rally organised by Jatiyo Nari Shramik Trade Union Kendra (National Women Workers Trade Union Centre). Photo: Soman. Available at:

https://commons.wikimedia.org/wiki/File:8marchrallydhaka (55).JPG)

\section{Conclusion}

In this article I explored how binary framings were used by the Islamists and countered by the feminists to make claims over the state. These binary framings positioned Bangladeshi women at opposite ends of the spectrum by dividing them between 'Muslim/religious/moral/authentic/traditional' 
or 'Bengali/secular/immoral/Westernised/modern' and erased the complex position religion has in the lives of Bangladeshi women. So what does the Bangladesh case tell us? The analyses of the genealogies of the binary framings and the contentious episodes when these framings were deployed reveal the following points.

These binary framings are used by religious political parties and the ulema to delegitimise the claims made by women's movement activists. By emphasising that women's groups espouse a Westernised vision of modernity, they question the authenticity and representative nature and the legitimacy of the changes proposed by women's rights groups. The analyses of the various contentious episodes also reveal that the binary framings have adverse implications for women's empowerment and state's accountability towards women. In the cases of the ban on fatwas and the NWDP, the state had backtracked and watered downed largely positive measures taken to advance women's rights. In both cases, state's accountability for promoting gender equity and the ability to protect the interests of female citizens have been significantly diminished.

The Bangladesh case also reveals the disconnect that exists between the individual women's experience of religious subjectivities as empowering and their expression of collective agency that may have an adverse impact on women's rights. Undeniably, women who are members of the religious political groups and Qu'ran reading groups are empowered through their engagement with religion. However, they also hold specific visions of what women's position in society is and what the state should or should not do in terms of policy and legal reforms. Their support for the visions that limit women's role in the public sphere exists as a counter-narrative to the visions espoused by the women's movement actors. The religious women's 
group's willingness to engage with the public on policy reform matters also raises questions about whether they could be mobilised by political parties for causes that are distinctively anti-women. Admittedly, the women in religious groups covered in this paper do not subscribe to the extreme views held by some of the Islamists groups. However, the possibility of women in religious groups mobilising for causes that are distinctively antiwomen, raises the need to explore the broader implication of individual women's religious subjectivity and its link to collective agency not only in Bangladesh but other Muslim majority contexts.

Academic research on religion and women's empowerment in Bangladesh have explored how positionality of both of the researcher and the participants influenced interpretations. However the location or context within which religion is empowering to women should be given equal weight as positionality to understand how the boundaries are set for women who do not fit the category of Muslim/religious/moral/authentic women in Bangladesh (and also in similar contexts). The construction of the binaries which promote 'virtuous womanhood' based on religion in a Muslim majority location bears political risk for feminists and their work.

In electoral politics, while religious parties may not secure a large percentage of the votes in Bangladesh, taking a pro-gender equity stance rarely generates popular electoral support. In addition, women do not vote as a bloc on these issues. Women's rights activists have a lot less to offer to the ruling elites in terms of patronage or numerical support. The popular appeal of Islam and the fear of being branded anti-Islamic allow religious groups to have veto power in matters related to women's rights that challenge deep-seated cultural and religious norms. While strategies for countering binary framings by appealing to the nationalist vision, the spirit 
of 1971 and international obligations of the state have been effective in the politics of representing women's empowerment, these framings have their limits, as we saw in the way state had backtracked. In fact, in recent years the AL has shifted its position and now has close relations with Hefazat E Islam to counter the rise of extremist groups linked to global terrorist networks in Bangladesh. The $A L$ is vulnerable to pressure from religious quarters given its legitimacy has been questioned after the 2014 elections, which was boycotted by major opposition parties.

One of the ways that women's movement actors have been able to remain relevant is by weaving their demands with the reputation the AL has built around being a government that delivers social development. Women's empowerment is a major part of this narrative of development success (Hossain, 2017). But is this a sustainable strategy to engage with the state?

The re-introduction of religious into the political space in the last decades nationally, regionally and globally coupled with Bangladesh's own historical experience with religious nationalism may mean that the space to raise doctrinal issues may shrink further and the strategies that were effective in the past to engage state actors may not work. The framings that are used such as universal rights and the types of actors who may support women's movement will change.

In fact, the women's movement faces significant challenges at present which means very difficult trade-offs. The rise of social media, which is extensively used by the new wave of Islamist groups, means that women's movement actors have to fight battles not just in the streets but also in the digital space, where they lack skills. The waning of donor power in 
Bangladesh means that the avenue that women's movement actors have generally used to place pressure on the state to promote women's empowerment (albeit sometimes a narrow donor vision) is limited. And the rise of extreme right ideology worldwide that vilifies Muslims, both in the Western world but also in neighbouring India, coupled with the rise of political Islam inside Bangladesh and in other Muslim majority contexts, including extreme right thinking in Saudi Arabia and Iran that interpret gender roles based on a crude reading of the Qu'ran, may mean that binary framings will be rife and the space for promoting the women's empowerment agenda that aligns with a liberal vision may be shrinking.

Dr Sohela Nazneen is Fellow based at the Institute of Development Studies. She has sixteen years of research, teaching, policy analysis and advocacy experience on gender and development issues. Her research largely focuses on gender and governance, women's economic empowerment, violence against women, and feminist movements in South Asia and sub Saharan Africa. Sohela has published on these issues, including in World Development, Studies in Family Planning, Conflict, Security and Governance and Women's Studies International Forum. Her forthcoming publication is a co-edited book - Negotiating Gender Equity in the Global South: The Politics of Domestic Violence Policy Making from Routledge.

\section{References}

Asadullah, M. and Chaudhury, N. (2007) Holy alliances: public subsidies, Islamic High Schools and female schooling in Bangladesh. Paper presented at Royal Economic Society Conference at University of Warwick, 11-13 April. 
Azim, F. (2017) Secularism and women's movement in Bangladesh. In: Mukhapadhyaya, M. ed., Feminist subversions and complicity. New Delhi: Zubaan.

Bangladesh Bureau of Statistics (2010) The Statistical Yearbook, BBS: Dhaka.

BBC, (2016) Bangladesh siege: 20 killed at Holey Artisan Bakery. 2 July (Accessed 18 February 2017).

Boussou, J. (2013) Bangladesh's radical Muslims uniting behind Hefazat E Islam, The Guardian, 30 July 30.

Chowdhury, E. (2009) Transnationalisms reversed: engaging religion, development and women's organizing in Bangladesh. Women's Studies International Forum, 32 (6): 414-23.

The Daily Star (2008) Women, human rights bodies demand scrapping of review body. 22 April 2008.

Dhaka Tribune (2013) Hefazat E Islam clash with opponents, 7April 2013. The Economist (2017) The battle between Bangladesh's two Begums is over. 7 December. 
Griffiths, M. and Hasan, M. (2015) Playing with fire: Islamism and politics in Bangladesh. Asian Journal of Political Science, 23 (2): 226-41.

Haq, N. (2011) Women defy Islamic clergy. [online]. Inter Press Service. (Accessed 28 April 2011).

Harrison, F. (2015) Political Islam and the elections in Bangladesh, UK: New Millennium.

Hartman, B. and Boyce, J. (1983) A Quiet violence, Dhaka: UPL.

Hashemi, T. I. (2000) Women and Islam in Bangladesh: beyond subjection and tyranny. London: Mcmillan.

Hashemi, T. I. (1995) Women and Islam: Taslima Nasrin, society and politics in Bangladesh. South Asia: Journal of South Asian Studies, 18(2): 23-48.

Hassan, M. (2013) The political settlement in a limited access order: the case of Bangladesh. ESID Working Paper Series No 23.Manchester: University of Manchester.

Hassan, M. and Nazneen, S. (2017) Violence and the breakdown of the political settlement: an uncertain future for Bangladesh. Conflict, Security and Development, 17 (3): 205-23. 
Hossain, N. (2017) The aid lab: understanding Bangladesh's unexpected success. Oxford: Oxford University Press.

Huq, M. (2008) Reading the Qu'ran in Bangladesh: the politics of 'belief' among Islamist women. Modern Asian Studies, 42(2/3): 457-88.

Huq, S. (2010) Negotiating Islam: conservatism splintered authority and empowerment in urban Bangladesh. IDS Bulletin, 41 (2): 97-105.

Hussain, N.A. (2010) Religion and modernity: gender and identity politics in Bangladesh. Women's Studies International Forum, 33: 325-33.

Jahan, R. (1995) Men in Purdah and women in public: Rokeya's dreams and women's struggles in Bangladesh. In: Basu, A. (ed.) The challenges of local feminisms: women's movement in global perspective. Boulder: Westview Press.

Jahan, R. (1972) Pakistan: a failure in national integration. New York: Columbia University Press.

Kabeer, N.(1991) The quest for national identity: women, Islam and the state in of Bangladesh. In: Kandiyoti, D. (ed.) Women, Islam and the state. London: Macmillan.

Kabeer, N. (1989) Subordination or struggle: New Left Review, 168. 
Karim, L. (2004) Democratizing Bangladesh: state, NGOs and militant Islam. Cultural Dynamics, 16 (2/3): 291-318.

Mahmood, S. (2005) The politics of piety: The Islamic revival and feminist subject. Princeton University Press.

Naher, A. (2010) Defending Islam and women's honor against NGOs in Bangladesh. Women's Studies International Forum, 33: 316-24.

The New York Times (2011) Bangladesh: Islamic strike shuts cities, 4 April 2011.

Nazneen, S. and Sultan, M. (ed.) (2014) Voicing demands: feminist activism in transitional contexts, London: Zed Books.

Nazneen. S. and Masud, R. (2017) The politics of promoting gender equity in Bangladesh. ESID working paper series no 76, Manchester: University of Manchester.

Riaz, A. (2014) A crisis of democracy in Bangladesh. Current History, 113 (762): 150-56.

Rozario, S. (1992) Purity and communal boundaries: women and social change in a Bangladeshi village. London: Zed Books. 
Sabir, M. (2013) Hefazat E Islam: Islamist coalition. [online]. 6 May 2013, BBC, Available from: http://www.bbc.co.uk/news/world-asia-22424708 (Accessed 18 February 2018).

Sabur, S. (2013) The enemy of my enemy is my friend. Alal O Dulal blog, Available from: http://dulal18.rssing.com/chan19793025/all_p1.html(Accessed 18 February 2018).

Shahid, T. E. (2017) Imaginary lines? Islam, secularism and the politics of family laws in Bangladesh. Unpublished DPhil thesis, University of Oxford.

Shehabuddin, E. (2008a) Jamat I Islami, Bangladesh: women, democracy and the transformation of Islamic politics. Modern South Asian Studies, 42 (2/3): 577-603.

Shehabuddin, E. (2008b) Reshaping the holy: democracy, development and Muslim women in Bangladesh. New York: Columbia University Press.

Siddiqui, D. (2006) In the name of Islam? Gender, politics and women's rights in Bangladesh. Harvard Asia Quarterly, X(I): 1-13.

Sobhan, S. (1980) Legal status of women in Bangladesh. Dhaka: BILIA.

Sobhan, R. (2015) From two economies to two nations: my journey to Bangladesh. Dhaka: The Daily Star Books. 
White, S. C. (2010) Domains of contestations: women's empowerment and Islam in Bangladesh. Women's Studies International Forum, 33: 33444.

Women for Women (1975) Situation of women in Bangladesh. Dhaka: Women for Women.

Yasmin. L. (2016) The well of the past: reinterpreting secularism after

9/11. Unpublished PhD thesis, Macquarie University, Sydney.

\section{Notes}

\footnotetext{
${ }^{1}$ Hefazat alleged that it contained a clause on equal inheritance, although it does not. See Shahid (2017).

${ }^{2}$ See Nazneen and Sultan (2014) for details of this project.

${ }^{3}$ It should be noted that the civil and penal codes in Bangladesh do not follow the Shari'a, except for matters related to personal law for Muslims.

${ }^{4}$ See Asadullah and Chaudhury (2007) or Harrison (2015) for details on madrassah education; see Hussain (2010) for details on Hibut Tahrir and establishment of English medium schools.

${ }^{5}$ The practices of the NGO sector in 'delivering development' are open to question and many of these practices are exploitative (Karim, 2004).

${ }^{6}$ Nasrin later fled the country and lives in exile.

${ }^{7}$ Religious edict- this ban was later curtailed by the Supreme Court in 2011.

${ }^{8}$ Formed in 1989, registered with the NGO bureau.
}

\section{To cite this article:}

Nazneen, S. (2018). Binary Framings, Islam and Struggle for Women's Empowerment in Bangladesh. Feminist Dissent, (3), 194-230. Retrieved from: https://journals.warwick.ac.uk/index.php/feministdissent/index 